\title{
POTRET PENYEDERHANAAN BIROKRASI PADA ERA REFORMASI BIROKRASI
}

\section{PORTRAIT OF BUREAUCRATIC TRIMMING IN THE BUREAUCRATIC REFORM ERA}

\author{
Syakib Arsalam \\ Pusat Pelatihan dan Pengembangan dan Kajian Manajemen Pemerintahan \\ Lembaga Administrasi Negara \\ Jl. Raya Baruga Nomor 48, Antang, Makassar \\ E-mail: arsalam21@gmail.com
}

Naskah diterima tanggal 22 November 2020. Naskah direvisi tanggal 28 Desember 2020.

Naskah disetujui tanggal 31 Desember 2020

\begin{abstract}
Abstrak
Penataan/penguatan kelembagaan merupakan bagian dari delapan area perubahan Reformasi Birokrasi, Periode I dan II Reformasi Birokrasi (RB) bertujuan untuk mewujudkan efesiensi dan efektifitas dan organisasi yang tepat ukuran, tepat fungsi, tidak tumpang tindih dan bersinergi antar instansi, kedua tujuan RB tersebut menjadi cikal bakal dari munculnya penyederhanaan birokrasi pada Periode III RB. Penyederhanaan birokrasi menjadi langkah yang besar didalam melakukan perubahan organisasi dan birokrasi yang belum ditemukan di dalam Periode I dan II Reformasi Birokrasi, sehingga membutuhkan usaha bersama untuk mewujudkan penyederhanaan birokrasi.
\end{abstract}

Kata Kunci: Reformasi Birokrasi, penyederhanaan birokrasi dan usaha bersama

\begin{abstract}
Institutional structuring / strengthening is part of the eight areas of change for Bureaucratic Reform, Period I and II Bureaucratic Reform (RB) aims to achieve efficiency and effectiveness and an organization that is the right size, right function, does not overlap and synergize between agencies, the two objectives of the RB are the forerunners of the emergence bureaucratic simplification in Period III RB. Bureaucratic Trimming is a major step in carrying out organizational and bureaucratic changes that have not been found in Periods I and II of Bureaucratic Reform, so that it requires joint efforts to realize Bureaucratic Trimming .
\end{abstract}

Keywords: Bureaucratic Reform, Bureaucratic Trimming and joint efforts

\section{PENDAHULUAN}

Reformasi birokrasi sudah berjalan kurang lebih 10 tahun dengan 3 periode dari 4 periode yang diamanatkan didalam Perpres No. 8 Tahun 2010 Tentang Grand Design Reformasi Birokrasi 2010 - 2025. Semangat reformasi awalnya dimulai setelah terjadinya krisis di tahun 19971998. Gelombang reformasi didorong oleh gerakan mahasiswa untuk segera melakukan perubahan. Pemerintah dianggap tidak dapat mengatasi lonjakan harga dimasa krisis, padahal upaya pemerintah sudah dilakukan (Tirto.id, 2020).

Tuntutan mahasiswa sebagai pengejawantahan dari keiinginan masyarakat untuk segera melakukan perubahan. Reformasi akhirnya masuk kedalam sistem pemerintahan. Untuk merespon reformasi tersebut akhirnya di 
undangkanlah UU No. 28 Tahun 1999 yang merupakan bagian dari tututan reformasi yang tertuang di dalam Tap MPR :
a. Tap MPR RI Nomor X/MPR/1998 tentang Pokok-Pokok Reformasi Pembangunan dalam rangka Penyelamatan dan Normalisasi Kehidupan Nasional

b. Tap MPR RI Nomor XI/MPR/1998 tentang Penyelenggaraan Negara yang Bersih dan Bebas KKN.

Gerakan reformasi di segala lini sudah mulai terbuka, secara bertahap reformasi berjalan di bidang politik, ekonomi dan hukum. Kebijakan reformasi birokrasi awalnya diatur didalam Permenpan No. 15 Tahun 2007 tentang Pedoman Pelaksanaan Reformasi Birokrasi, sebagai langkah awal reformasi birokrasi difokuskan pada 3 area perubahan reformasi birokrasi, yakni kelembagaan, ketatalaksanaan (business process), dan manajemen SDM aparatur (Sugiarto, 2011).

Tema Reformasi Birokrasi (RB) terus berkembang dan banyak kalangan akademisi yang membedahnya sebagai karya ilmiah, diantaranya Mifta Thoha, Kwik Yan Gie, Agus dwiyanto, dan masih banyak lagi. Menurut akademisi bahwa alasan munculnya gerakan RB diantaranya sebagai berikut:

1. Tidak adanya akuntabilitas publik, tidak adanya transparansi dan kurang adanya pertanggung jawaban selama pemerintahan yang lalu yang dilakukan oleh pemerintah terhadap tindakan publik, karena pendekatan kekuasaan sangat sentral.

2. Kelembagaan dan ketatalaksanaan, birokrasi di tingkat pusat maupun daerah cenderung semakin banyak dan tambun. Dengan kondisi yang demikian maka organisasi akan cenderung kaku dan lambat dalam mengantisipasi permasalahan yang timbul .

3. Faktor kekuasaan, insentif, akuntabilitas, dan budaya birokrasi semuanya terpusat di birokrasi yang melaksanakan kebijakan, maka dibutuhkan gerakan reformasi
birokrasi(Gie, 2003 dan (Thoha, 2002).

Isu-isu yang berkembang di lingkup RB semakin meningkat sehingga diperlukan gerakan yang lebih masif dan terstruktur di lingkungan pemerintah, kemudian lahirlah Perpres No. 81 Tahun 2010 tentang Grand Design Reformasi Birokrasi 2010-2025. Dalam perpres tersebut terdapat 8 (delapan) area perubahan yaitu 1) Organisasi, 2) Tatalaksana 3) Peraturan Perundangundangan, 4) Sumber Daya Aparatur, 5) Pengawasan, 6) Akuntabilitas, 7) Pelayanan Publik, 8) Pola Pikir (mind set) dan Budaya Kerja(culture set) Aparatur, 8 area tersebut diharapkan dapat membawa perubahan untuk menjawab tantangan dari reformasi.

Istilah Grand Design Reformasi Birokrasi dalam desain RB di Perpres No. 81 Tahun 2010, memiliki arti rancangan induk yang berisi arah kebijakan pelaksanaan reformasi birokrasi nasional untuk kurun waktu 2010- 2025. Grand Design akan di operasionalisasikan dalam bentuk Road Map 5 tahunan, seperti yang dituangkan di dalam PermenPan-Rb No. 20 Tahun 2010 tentang Road Map Reformasi Birokrasi 2010 - 2014. Setiap tahun instansi akan melaksanakan agenda tahunan RB sesuai dengan kebutuhan instansi masing-masing serta program mikro dan makro yang diusung untuk tiaptiap agenda perubahan.

Pentingnya reformasi birokrasi dalam konteks kelembagaan untuk menghindari adanya tumpang tindih pelaksanaan tugas dan fungsi, upaya ini dapat dilakukan dengan redefenisi kelembagaan birokrasi termasuk melakukan penataan kelembagaan sesuai dengan standard operating procedure atau SOP (Gie, 2003). Penataan kelembagaan akan berdampak pada perubahan SOP yang ada didalam instansi tersebut, karena struktur organisasi merupakan gambaran proses

Secara khusus sasaran dari reformasi birokrasi adalah (1)Berkurangnya secara nyata praktek korupsi pada birokrasi, dan dimulai dari tataran (jajaran) pejabat yang paling atas; (2) Terciptanya sistem kelembagaan dan ketatalaksanaan 
pemerintahan yang bersih, efisien, efektif, transparan, profesional dan akuntabel; (3) Terhapusnya aturan, peraturan dan praktek yang bersifat diskriminatif terhadap warga negara, kelompok, atau golongan masyarakat; (4) Meningkatnya partisipasi masyarakat dalam proses kebijakan publik; dan (5) Terjaminnya konsistensi seluruh peraturan pusat dan daerah, dan tidak bertentangan dengan peraturan dan perundangan di atasnya.(Ginting. R, 2011) Istilah yang dikenal dengan penyederhanaan birokrasi yang menjadi bagian dari ukuran keberhasilan reformasi birokrasi pada periode III, merupakan bagian dari dinamika penataan organisasi/ kelembagaan yang ada didalam dokumen Reformasi Birokrasi. Kelembagaan menjadi salah satu dari 8 area perubahan yang diinginkan Reformasi Birokrasi, istilah yang digunakan dengan penyederhanaan birokrasi merupakan lompatan untuk mendorong birokrasi melakukan perubahan besar dengan memangkas jabatan struktural eselon III dan eselon IV. Menarik dalam penelitian ini untuk diungkap Bagaimana potret penyederhanaan birokrasi dalam dokumen Reformasi Birokrasi ? yang selama ini berjalan mulai dari periode Reformasi Birokrasi 2011-2014, periode Reformasi Birokrasi 2015-2019 dan periode 20202025.

\section{Tujuan Penelitian}

Untuk menganalisis upaya

Reformasi Birokrasi didalam melakukan penataan organisasi/kelembagaan.

\section{TINJAUAN PUSTAKA}

\section{Penataan Kelembagaan dalam Reformasi Birokrasi}

Kelembagaan berasal dari kata bureaucracy (Bahasa Inggris, bureaucracy), diartikan sebagai suatu organisasi yang memiliki rantai komando dengan bentuk piramida, dimana lebih banyak orang berada ditingkat bawah dari pada tingkat atas, biasanya ditemui pada instansi yang sifatnya administratif maupun militer (Sinambela, 2008). Pada rantai komando ini setiap posisi serta tanggung jawab kerjanya dideskripsikan dengan jelas dalam organisasi. Organisasi ini pun memiliki aturan dan prosedur ketat sehingga cenderung kurang fleksibel. Ciri lainnya adalah biasanya terdapat banyak formulir yang harus dilengkapi dan pendelegasian wewenang harus dilakukan sesuai dengan hierarki kekuasaan.

Ciri organisasi yang mengikuti sistem kelembagaan ini adalah pembagian kerja dan spesialisasi, orientasi impersonal, kekuasaan hirarkis, peraturan-peraturan, karir yang panjang, dan efisiensi. Cita-cita utama dari sistem kelembagaan adalah mencapai efisiensi kerja yang seoptimal mungkin. Menurut Weber dalam bukunya Snambela bahwa organisasi kelembagaan dapat digunakan sebagai pendekatan efektif untuk mengontrol pekerjaan manusia sehingga sampai pada sasarannya, karena organisasi kelembagaan punya struktur yang jelas tentang kekuasaan dan orang yang punya kekuasaan mempunyai pengaruh sehingga dapat memberi perintah untuk mendistribusikan tugas kepada orang lain (Sinambela, 2008).

Faktor yang mempengaruhi organisasi sangat luas. Menurut Sondang, P. Siagian (2007) ada 9 (sembilan) yang mempengaruhi perubahan organisasi yaitu:

1. Tantangan Utama di Masa Depan

2. Perubahan dalam Konfigurasi

Ketenagakerjaan

3. Tingkat Pendidikan Para Pekerja

4. Teknologi

5. Situasi Perekonomian

6. Berbagai Kecenderungan Sosial

7. Faktor Geopolitik

8. Persaingan

9. Pelestarian Lingkungan

Menurut kedeputian kelembagaan kementerian PANRB ada 8 (delapan) fokus yaitu (1) penyusunan Grand Design Kelembagaan Pemerintah; (2) penataan organisasi Kementerian Negara; (3) penataan organisasi LPNK; (4) Evaluasi dan penataan organisasi UPT; (5) evaluasi dan penataan Satuan Kerja PPK-BLU; (6) penataan organisasi - organisasi Sekretariat Lembaga Negara; (7) penataan organisasi Lembaga Non Struktural; dan (8) evaluasi dan penataan Kelembagaan Pemerintah Daerah (Komaruddin, 2012). 
Road Map Reformasi Biorkrasi (Road Map RB) telah memasuki tahap 3 (ketiga) sesuai dengan Grand Design RB. Pada periode I (2010-2014) difokuskan pada penguatan birokrasi pemerintah dalam rangka mewujudkan pemerintahan yang bersih dan bebas korupsi, kolusi, dan nepotisme, meningkatkan kualitas pelayanan publik kepada masyarakat, serta meningkatkan kapasitas dan akuntabilitas kinerja birokrasi. Pada periode II (20152019) juga dilanjutkan upaya yang belum dicapai pada berbagai komponen strategis birokrasi pemerintah pada lima tahun pertama. Pada periode III (2020-2024), reformasi birokrasi dilakukan melalui peningkatan kapasitas birokrasi secara terus-menerus untuk menjadi pemerintahan kelas dunia sebagai kelanjutan dari reformasi birokrasi pada lima tahun kedua.

Dalam reformasi birokrasi ada beberapa istilah yang digunakan untuk program / kegiatan kelembagaan/ organisasi. Pada periode I, istilah yang digunakan adalah penataan organisasi. Pada periode II, menggunakan istilah penguatan kelembagaan. Sedangkan pada periode III, istilah yang digunakan adalah penyederhanaan organisasi. Perbedaan istilah organisasi dan kelembagaan di dalam Road Map RB. Penataan organisasi di dalam dokumen Road Map RB menunjuk pada restrukturisasi pada tugas dan fungsi unit kerja organisasi, sedangkan penguatan kelembagaan merujuk pada ukuran, fungsi dan sinergitas. Hasil yang diharapkan dari penataan organisasi adalah adanya peta tugas dan fungsi unit kerja organisasi sedangkan untuk penataan kelembagaan diharapkan organisasi tepat ukuran, tepat fungsi, tidak tumpang tindih dan bersinergi antar instansi. Istilah kelembagaan merujuk pada hubungan antara instansi pemerintah seperti keterkaitan antara tugas dan fungsi yang berbeda sehingga tidak menimbulkan tumpang tindih tetapi tetap ada sinergi antara instansi pemerintah yang merupakan perwujudan dari tata pemerintahan. Sedangkan organisasi merujuk pada tugas dan fungsi instansi pemerintah ditingkat Kementerian/
Lembaga/ Pemerintah Daerah yang dianggap belum berjalan diawal Reformasi Birokrasi .

Pada periode III RB muncul istilah penyederhanaan organisasi. Salah satu faktor yang menyebabkan istilah penyerderhanaan orgainsasi merupakan tindak lanjut pidato Presiden pada sidang paripurna MPR RI pada tanggal 20 Oktober 2019. Penyederhanaan organisasi tidak dapat dipisahkan dari periode I dan II RB sebagai upaya penataan dan penguatan organisasi. Penyederhanaan organisasi dilakukan untuk mendapatkan profil kelembagaan pemerintah yang tepat fungsi, tepat proses dan tepat ukuran, yang pada periode I dan II RB belum tercapai secara maksimal. Sehingga pada periode III penyederhanaan organisasi menjadi langkah strategis untuk mendorong penataan dan penguatan organisasi.

$$
\text { Potret program organisasi/ }
$$

kelembagaan yang ada didalam RB mengindikasikan adanya keragaman. Interpretasi terhadap program organisasi tersebut Penataan organisasi/kelembagaan berjalan sesuai dengan tujuan yang ingin dicapai pada setiap periode $R B$. Pendekatan yang digunakan oleh masingmasing organisasi terhadap Road Map RB juga berbeda, karena harus disesuaikan dengan kebutuhan organisasi. Setiap Kementerian/Lembaga akan dipetakan kebutuhan organisasinya selanjutnya akan menyusun agenda perubahan organisasi.

\section{Perangkat Daerah}

Jika ditarik dari masa reformasi birokrasi dihubungkan dengan perangkat daerah, maka terdapat dua aturan yang satu masa dengan reformasi birokrasi di bidang kelembagaan yaitu 1) Peraturan Pemerintah No. 41 Tahun 2007 tentang Organisasi Perangkat Daerah dan 2) Peraturan Pemerintah No. 18 Tahun 2016 tentang Perangkat Daerah. Masa reformasi birokrasi dari tahun 2004-2009 didalam Perpres No. 81 Tahun 2010 dikenal dengan Reformasi Birokrasi Gelombang I, sehingga Peraturan Pemerintah No. 41 Tahun 2007 dapat dikategorikan sebagai bagian dari aturan perangkat daerah di era Reformasi Birokrasi. 
Pada PP No. 8 Tahun 2003 telah membatasi jumlah maksimal perangkat daerah PP No. 41 Tahun 2007 merupakan penjabaran dari UU No. 32 Tahun 2004 tentang Pemerintah Daerah sebagai mana disebutkan didalam 128 yang berbunyi "susunan organisasi perangkat daerah ditetapkan dengan PERDA sesuai dengan pedoman yang ditetapkan pemerintah". PP No. 41 Tahun 2007 yang merupakan pengganti dari PP No. 8 Tahun 2003 ini diterbitkan dengan dua semangat, yaitu semangat untuk mengatasi kesimpangsiuran nomenklatur beserta tupoksi dan rentang kendali organisasi dan semangat untuk membatasi sekaligus menyeragamkan jumlah kelembagaan daerah.

Besaran kelembagaan pemerintah daerah akan disesuaikan dengan penilaian daerah masing-masing, sehingga jumlah perangkat daerah menjadi beragam. Daerah yang memiliki skor penilaian yang rendah akan berdampak pada kurangnya perangkat daerah yang ada di daerah tersebut, sehingga dapat menimbulkan hilangnya koordinasi antara pemerintah pusat dengan pemerintah daerah yang terwadahi didalam nomengklatur kementerian. Ini salah satu faktor yang mempengaruhi sehingga tidak berjalannya koordinasi antara pemerintah daerah dengan pemerintah pusat pada masa PP No. 8 Tahun 2003. setelah dilakukan perubahan terhadap Undang- Undang Pemerintah Daerah maka lahirlah PP No. 41 Tahun 2007 ada beberapa perbedaan antara aturan sebelumnya.

Paling tidak ada tiga alasan yang mendasari kehadiran PP No. 41 Tahun 2007 diantaranya: (1) Kesimpangsiuran nomenklatur pemerintaah daerah dan pusat, (2) Variasi besaran kelembagaan, dan (3) struktur organisasi pemerintah daerah cenderung sangat gemuk sehingga menghisap sebagian besar alokasi APBD untuk belanja aparatur (Dungga, 2010). Ketiga alasan tersebut di atas yang paling berpengaruh langsung terhadap kinerja daerah ada pada alokasi APBD, jika daerah tersebut mendapatkan skor yang rendah pada indikator nilai, maka akan mempengaruhi besaran pengelolaan
APBD. Sehingga daerah akan berusaha untuk memperbesar nomengkaltur organisasinya.

Pembentukan organisasi perangkat daerah yang berupa Dinas atau Badan diklasifikasikan berdasarkan Tipe A (beban kerja yang besar), Tipe B (beban kerja yang sedang) dan Tipe $\mathrm{C}$ (beban kerja yang kecil). Penentuan beban kerja bagi Dinas didasarkan pada jumlah penduduk, luas wilayah, besaran masingmasing Urusan Pemerintahan yang menjadi kewenangan Daerah, dan kemampuan keuangan Daerah untuk Urusan Pemerintahan Wajib dan berdasarkan potensi, proyeksi penyerapan tenaga kerja, dan pemanfaatan lahan untuk Urusan Pemerintahan Pilihan. Sedangkan besaran beban kerja pada Badan berdasarkan pada jumlah penduduk, luas wilayah, kemampuan keuangan Daerah, dan cakupan tugas. Daerah dikelompokkan menjadi:

a. Daerah Kecil (Nilai <40) : - Setda paling banyak 3 (tiga) asisten Sekretariat DPRD. - dinas paling banyak 12 (dua belas). - lembaga teknis daerah paling banyak 8 (delapan).

b. Daerah Sedang (Nilai 40-70) - Setda paling banyak 3 (tiga) asisten Sekretariat DPRD - Dinas paling banyak 15 (lima belas) - lembaga teknis daerah paling banyak 10 (sepuluh).

c. Daerah Besar (Nilai >70) - Setda, terdiri dari paling banyak 4 (empat) asisten - sekretariat DPRD - dinas paling banyak 18 (delapan belas) lembaga teknis daerah paling banyak 12 (duabelas).

Jumlah Perangkat Daerah dalam PP Nomor 41 tahun 2007 telah dibatasi, namun di luar jumlah yang sudah dibatasi tersebut masih memungkinkan untuk menambah perangkat daerah apabila ada perintah peraturan perundang-undangan. Sementara itu, jumlah bidang telah dibatasi antara 4-7 saja Peraturan Pemerintah No. 18 Tahun 2016 tentang Perangkat Daerah penjabaran dari UndangUndang No. 23 Tahun 2014 Pemerintah Daerah. Ada beberapa hal yang sama 
diatur didalam PP No. 41 Tahun 2007. Pembentukan perangkat Derah sesuai dengan jumlah fungsi pendukung, urusan pemerintahan dan fungsi penunjang. Fungsi pendukung, urusan pemerintahan dan urusan pemerintahan dikelompokkan menjadi :

a. Fungsi atau Urusan dengan beban besar, diwadahi perangkat daerah tipe A.

b. Fungsi atau Urusan dengan beban sedang, diwadahi perangkat daerah tipe B

c. Fungsi atau Urusan dengan beban kecil, diwadahi perangkat daerah tipe C

d. Fungsi atau Urusan dengan beban sangat kecil, tidak menjadi perangkat namun bisa berupa Bidang, atau Seksi/ Subbidang.

Jumlah perangkat daerah kemungkinan lebih banyak dari sebelumnya, namun jumlah struktur perangkat daerah secara keseluruhan akan berkurang karena adanya perbedaan jumlah bidang dan kasi pada setiap perangkat daerah. jumlah bidang minimal 2 maksimal 4. Disamping itu, pemerintah daerah provinsi dan kabupaten/ kota tidak dapat menambah perangkat daerah lain di luar yang sudah ditentukan. Bahkan untuk memperkecil struktur Birokrasi, Pemerintah Daerah Dapat menurunkan tipe perangkat daerah

\section{Metode penelitian}

Kajian ini dilakukan dengan menggunakan studi kepustakaan (library research) melalui kajian berbagai referensi dan dokumen yang berkaitan dengan reformasi birokrasi. Dalam memperkaya data program dan capaian penyederhaan birokrasi dianggap penting untuk menelusuri berita atau dokumen yang di Publikasikan oleh Kementerian PAN \& $\mathrm{RB}$ melalui website.

\section{HASIL DAN PEMBAHASAN Road Map Reformasi Birokrasi 2010 - 2014}

Road Map RB 2010 - 2014 diatur didalam Permenpan No. 20 Tahun 2010 didalam program penataan organsiasi pada tingkat makro ada dua sasaran yang ingin dicapai yaitu 1) Menurunnya tumpang tindih tugas pokok dan fungsi antarKementerian/Lembaga dan Pemerintah Daerah; 2) Meningkatnya kapasitas kelembagaan dalam melaksanakan tugas pokok dan fungsi K/L dan Pemda. Ada 16 program makro penataan dan penguatan organisasi, sebagai berikut :

a. Penyusunan pedoman umum sistem kelembagaan pemerintah

b. Penyusunan pedoman evaluasi kelembagaan pemerintah

c. Penyusunan SOP penataan kelembagaan pemerintah

d. Pemantauan dan evaluasi organisasi kementerian

e. Penyusunan pedoman umum kelembagaan LPNK

f. Pemantauan dan evaluasi organisasi LPNK

g. Penyusunan pedoman umum kelembagaan instansi vertikal

h. Penyusunan pedoman umum kelembagaan UPT

i. Pemantauan dan evaluasi kelembagaan UPT

j. Penyusunan pedoman umum kelembagaan instansi pemerintah yang menerapkan PPK-BLU

k. Pemantauan dan evaluasi kelembagaan instansi pemerintah yang menerapkan PPK-BLU

1. Penyusunan pedoman umum kelembagaan sekretariat lembaga negara

m. Pemantauan dan evaluasi kelembagaan sekertariat lembaga negara

n. Penyusunan pedoman umum

kelembagaan sekertariat nonstruktural

o. Pemantauan dan evaluasi

kelembagaan lembaga non struktural

p. Pemantauan dan evaluasi kelembagaan pemerintah daerah.

Ke 16 Program tersebut diatas mengambarkan bagaimana upaya penataan dan penguatan organisasi awal pada RB di periode I. Program penataan dan penguatan organisasi sebagian besar terdiri atas penyusunan regulasi yang menjadi pedoman, penyusunan atau evaluasi terhadap organisasi. Setidaknya ada 6 regulasi yang muncul atau direvisi ditahun 
2011 sebagai regulasi yang digunakan dalam penataan dan penguatan organisasi yaitu:

1. Peraturan Presiden Nomor 47 Tahun 2009 tentang Pembentukan dan Organisasi Kementerian Negara sebagaimana telah beberapa kali diubah, terakhir dengan Peraturan Presiden Nomor 91 Tahun 2011

2. Peraturan Presiden Nomor 24 Tahun 2010 tentang Kedudukan, Tugas, dan Fungsi Kementerian Negara serta Susunan Organisasi, Tugas, dan Fungsi Eselon I Kementerian Negara sebagaimana telah beberapa kali diubah, terakhir dengan Peraturan Presiden Nomor 92 Tahun 2011

3. PermenpanRB Nomor 66 Tahun 2011 tentang SOP Penataan Kelembagaan Pemerintah

4. PermenpanRB Nomor 65 Tahun 2011 tentang Pedoman Umum Sistem Kelembagaan Pemerintah

5. Permenpan RB Nomor 68 Tahun 2011 tentang Pedoman Umum Kelembagaan Instansi yang Menerapkan Pola Pengelolaan Keuangan Badan Layanan Umum (PPK-BLU)

6. Peraturan Menpan 67 Tahun 2011 Pedoman Evaluasi Kelembagaan Pemerintah, diubah dengan Peraturan Menpan 20 Tahun 2018 tentang Pedoman Evaluasi Kelembagaan Instansi Pemerintah

Selain penguatan pada regulasi juga dilakukan audit/evaluasi organisasi yang dilakukan pada tahun 2012, audit organisasi ini dilakukan pada tiga organisasi dibawah rumpun yang sama yaitu; Kementerian PAN dan RB, LAN dan BKN. Hasil audit terhadap ketiga lembaga ini adalah down sizing yang diharapkan dapat menjadi model bagi organisasi $\mathrm{K} / \mathrm{L}$ lainnya. Organisasi Kementerian PANRB telah dirampingkan dari 6 deputi menjadi 4 deputi. Sedangkan LAN dilakukan perampingan dari 5 deputi menjadi 3 deputi, sementara di BKN dengan telah dirampingkan dari 5 deputi menjadi 4 deputi. Selanjutnya pada tahun 2013 dilakukan audit organisasi terhadap 16 Kementerian/Lembaga hasil audit/ evaluasi organisasi yang dilakukan oleh kemenPAN RB ditemukan bahwa ada dua kementerian yang belum berhasil melakukan down sizing.

Pada periode I RB pemerintah daerah juga pada masa ini, melakukan penataan kelembagaan berdasarkan PP No. 41 Tahun 2007 tentang Organisasi Perangkat Daerah. Terdapat dua kementerian yang memiliki kewenangan didalam penataan kelembagaan yaitu untuk tingkat kementerian penataan kelembagaan dilakukan oleh Kementerian PANRB sedangkan untuk Pemerintah Daerah dilakukan oleh Kementerian Dalam Negeri. Ada perbedaan antara evaluasi kelembagaan dengan audit organisasi yang dilakukan oleh Kementerian PANRB meskipun autputnya sama yaitu dapat memberikan rekomendasi untuk melakukan pengurangan jumlah struktur yang ada didalam organisasi.

Dalam melakukan audit organisasi yang dilakukan oleh Kementerian PANRB mengeluarkan pedoman tersendiri yang diatur didalam Peraturan Menpan 67 Tahun 2011 Pedoman Evaluasi Kelembagaan Pemerintah. Berbeda dengan evaluasi kelembagaan yang ada diaturan PP No. 41 Tahun 2007 jo Permendagri 57 Tahun 2007 memuat 1) Pembentukan, 2) Tugas dan fungsi OPD, 3) Besaran Organisasi, 4) Perumpunan bidang Pemerintahan, 5) Susunan Organisasi. Dalam melakukan evaluasi kelembagaan di tingkat pemerintah daerah cukup menggunakan PP No. 41 Tahun 2007 jo Permendagri 57 Tahun 2007. Kelima aspek yang dievaluasi tersebut akan memberikan output berupa rekomendasi perumpunan urusan pemerintahan didalam perangkat daerah. Perumpunan urusan tersebut disesuaikan dengan tipologi daerah masing-masing.

Permenpan No. 67 Tahun 2011 sebagai dasar audit organisasi memuat 3 aspek yaitu; kompleksitas, formalisasi, dan sentralisasi, ketiga aspek tersebut kemudian diturungkan ke dalam indikator yang lebih kecil. Dalam aspek kompleksitas bagaimana organisasi mengelola alur koordinasi antara unit kerja, melakukan kontrol pekerjaan dan 
membangun komunikasi sehingga setiap unit dapat bekerja dengan pekerjaan yang sudah terpisah-pisah dengan jelas (diferensiasi). sedangkan untuk aspek formalisasi merujuk pada seperti apa aturan-aturan, prosedur, instruksi dan komunikasi dibakukan sehingga tercapai standarisasi produk atau layanan yang diberikan. Pada aspek sentralisasi, seperti apa organisasi dalam melakukan pengambilan keputusan, semakin panjang struktur organisasi ke pusat pengambilan keputusan maka dapat menyita waktu yang lama. Ketiga aspek tersebut yang dijadikan tolok ukur didalam melakukan audit organisasi.

\section{Road Map Reformasi Birokrasi 2015 - 2019}

Dalam Road Map RB Periode II nama program untuk area perubahan organisasi adalah penguatan kelembagaan, setelah pada periode sebelumnya penguatan dan penataan organisasi. Berdasarkan hasil evaluasi terhadap penguatan dan penataan organisasi masih didapati beberapa permasalahan organisasi yaitu: 1) organisasi gemuk, secara makro maupun mikro; 2) fragmented dan tumpang tindih fungsi; dan 3) banyaknya UU yang mewajibkan pembentukan lembaga (di pusat dan di daerah) yang berpotensi over institution dan tumpang tindih tugas dan fungsi.

Salah satu capaian dari penguatan dan penataan organisasi pada periode I RB, semakin meningkatnya Kementerian/ Lembaga yang ikut didalam audit organisasi sampai pada tahun 2014 ada 19 kementerian, sehingga tercapai 34 Kementerian Kabinet Indonesia Bersatu II. Dalam praktik pelaksanaan audit organisasi yang dilakukan sejak tahun 2012 -2014 ada beberapa catatan yaitu

a. Kementerian/Lembaga dan pemda cenderung memaksimalkan jumlah unit organisasi;

b. Kementerian/Lembaga dan pemda belum memiliki komitmen yang kuat untuk membentuk kelembagaan yang efisien dan efketif;

c. Kecenderungan Undang-undang sektor yang Undang-undang
mengamanatkan pembentukan Kementerian/Lembaga;

d. Kriteria mengenai pembentukan, pengubahan, dan pembubaran Kementerian/Lembaga belum memadai

Tantangan dalam penataan organisasi di tingkat Kementerian/ Lembaga tidak sederhana berdasarkan hasil audit organisasi menemukan bahwa komitmen internal organisasi dan dukungan dari regulasi organisasi menjadi kunci untuk mempercepat tujuan dari penguatan dan penataan organisasi. Dalam internal organisasi harus terbangun kepercayaan bahwa untuk mencapai efesiensi dan efektifitas organisasi perlu dilakukan audit/evaluasi organisasi. serta mampu menerima hasil penyederhanaan organisasi. perubahan struktur organisasi bukan hal sederhana yang dipahami dengan pemangkasan struktur organisasi tetapi mengubah proses / mekanisme yang ada sebelumnya menjadi lebih sederhana dan mudah dilaksanakan.

Perubahan struktur berdasarkan audit organisasi harus melakukan peninjauan terhadap Undang-undang yang mengatur Kementerian/Lembaga tersebut. Beberapa kementerian/lembaga yang menjalangkan urusan negara pada sektor tertentu, bisa jadi diatur didalam beberapa undangundang. Jadi diperlukan mekanisme legislasi untuk melakukan penyederhanaan Kementerian/Lembaga tersebut.

Ada 7 harapan yang dibangun pada penguatan kelembagaan pada periode II RB sebagai berikut :

1. Meningkatnya kualitas pelaksanaan agenda reformasi birokrasi nasional;

2. Meningkatnya ketepatan ukuran, ketepatan fungsi dan sinergisme/ kesinergisan kelembagaan Kementerian/lembaga pemerintah non kementerian/lembaga non struktural;

3. Menurunnya tumpang tindih tugas dan fungsi antar Kementerian/Lembaga dan antar Kementerian/Lembaga dengan Pemerintah daerah;

4. Meningkatnya kejelasan pembagian kewenangan antara pemerintah pusat, pemerintah provinsi dan pemerintah kabupaten/kota;

5. Meningkatnya sinergisme 
kelembagaan antara instansi pemerintah pusat dan daerah;

6. Meningkatnya sinergisme dan penguatan kelembagaan pada masingmasing bidang pembangunan;

7. Meningkatnya kinerja aparatur

Harapan terhadap penguatan kelembagaan tersebut diharapkan dapat memperkuat organisasi pemerintah baik ditingkat Kementerian/Lembaga maupun ditingkat Pemerintah Daerah. Untuk itu perlu melakukan identifikasi terhadap program yang sudah dijalankan oleh Pemerintah di Periode II RB. Program penguatan kelembagaan dapat berupa kebijakan yang didesain dari Reformasi Birokrasi maupun kebijakan yang tidak berkaitan tetapi masih ada kaitannya dengan kelembagaan/ organisasi.

Perubahan PP No. 41 Tahun 2007 menjadi PP No. 18 Tahun 2016 tentang Pemerintah Daerah berdampak pada pengaturan kelembagaan di tingkat pemerintah daerah. Ada beberapa perbedaan anatara kedua aturan perangkat daerah tersebut diantaranya PP No. 18 Tahun 2016 Jumlah perangkat daerah kemungkinan lebih banyak disebabkan pengalihan kewenangan dari kabupaten/ kota ke provinsi dan pembentukan perangkat daerah berdasarkan hasil pemetaan beban urusan atau beban penunjang atau beban pendukung. sedangkan pada PP No. 41 Tahun 2007 perangkat daerah sudah dibatasi, namun di luar jumlah yang sudah dibatasi tersebut masih memungkinkan untuk menambah perangkat daerah apabila ada perintah peraturan perundang-undangan (Simarmata, 2008). Selanjutnya besaran struktur organisasi pada PP No. 41 Tahun 2007 jumlah bidang dibatasi antara 4-7 bidang sedangkan pada PP No. 18 Tahun 2016 jumlah bidang minimal 2 maksimal 4.

Ada dua Peraturan Kementerian Dalam Negeri untuk melaksanakan PP No. 18 Tahun 2016 yaitu Permendagri No. 5 Tahun 2017 tentang pedoman nomengklatur perangkat daerah Provinsi dan Daerah Kabupaten/Kota yang melaksanakan fungsi penunjang penyelenggaraan urusan pemerintahan dan Permendagri No. 99 Tahun 2018 Tentang Pembinaan dan Pengendalian Penataan Perangkat Daerah. Permendagri No. 5 Tahun 2017 dibuat untuk memperjelas urusan penunjang pemerintah daerah seperti perencanaan, keuangan, kepegawaian, pendidikan dan pelatihan, penelitian dan pengembangan dan fungsi penunjang lainnya yang belum dijelaskan didalam PP No. 18 Tahun 2016. Lima (5) urusan penunjang tersebut dapat di gabungkan berdasarkan perumpunan fungsi urusan sesuai dengan tipologi daerah( $\mathrm{A}, \mathrm{B}$ dan $\mathrm{C}$ ), dalam Permendagri No. 5 Tahun 2017 tersebut dilengkapi dengan uraian fungsi (tugas) yang telah digabungkan atau yang berdiri sendiri urusan penunjangnya.

Dalam Permendagri No. 99 Tahun 2018 mengatur mengenai bagaimana kewenangan Pemerintah Provinsi dan Kementerian dalam melaksanakan tugasnya didalam melakukan pembinaan dan pengendalian perangkat daerah di Tingkat Kabupaten/Kota. Pembinaan dan pengendalian perangkat daerah teridri dari 3 aspek yaitu struktur organisasi, budaya organisasi dan inovasi organisasi. Pemerintah Provinsi sebagai wakil pemerintah di daerah harus mampu melaksanakan tugasnya untuk mengendalikan besaran organisasi pemerintah daerah di tingkat Kabupaten/ Kota yang ada diwilayahnya. Dalam penataan kelembagaan sebagai bagian dari Reformasi Birokrasi peran Pemerintah Provinsi cukup penting untuk melaksanakan pembinaan dan pengendalian perangkat daerah yang selama ini masih dianggap tumpang tindih.

Tumpah tindih antara tugas dan fungsi perangkat daerah baik ditingkat Provinsi maupun di tingkat Kabupaten/Kota dalam Permendagri No. 99 Tahun 2018 seharusnya dapat diatas dengan dibukanya jalan untuk saling koordinasi antara Pemerintah Provinsi dan Pemerintah Kabupaten/Kota. Pemerintah Provinsi dapat melakukan pembinaan untuk pelaksanaan urusan pemerintah yang ada di Kabupaten/Kota dengan tetap melakukan singkronisasi urusan-urusan 
yang ada di Provinsi. Untuk menghindari tumpang tindih yang selama ini terjadi antara Pemerintah Provinsi dan Kabupaten/Kota.

Dalam Road Map Periode II RB (Permenpanrb No. 11 Tahun 2015) program penguatan kelembagaan ada 3 Kementerian/Lembaga yang terkait yaitu Kementerian PANRB, Lembaga Administrasi Negera dan Kementerian Dalam Negeri. Kegiatan dari program penguatan kelembagaan salah satunya adalah penataan kelembagaan, perlu melibatkan Pemerintah Provinsi untuk melaksanakan tugas sebagai pembina dan pengendali penataan perangkat daerah (Permendagri No. 99 Tahun 2018). Reformasi Birokrasi sebagai sebuah gerakan yang masif untuk mengatasi tumpang tindih dari tugas dan fungsi organisasi maka dibutuhkan peran yang lebih luas dari Kementerian/Lembaga dan Pemerintah Daerah. Untuk melakukan koordinasi dan membangun keterjalinan untuk membagi peran didalam pelaksanaan tugas dan fungsi organisasi.

\section{Road Map Reformasi Birokrasi 2020 - 2025}

Road Map RB Periode III bersama dengan awal periode kedua pemerintahan Jokowi, dalam periode kedua pemerintahan jokowi tuntutan akan perubahan kelembagaan menjadi salah satu dari 5 arahan presiden. Penguatan kelembagaan menjadi strategi dalam pelaksanaan misi Nawacita dan pencapaian sasaran Visi Indonesia 2045 yaitu : 1) Pembangunan SDM, 2) Pembangunan Insfrastruktur, 3) Penyederhaan Regulasi, 4) Penyederhanaan Birokrasi, 5) Transformasi Ekonomi. Penyederhanaan birokrasi diharapkan memangkas prosedur dan birokrasi yang panjang, untuk mendukung kemudahan berusaha (ekonomi) serta menekan berbagai biaya yang mengakibatkan ekonomi biaya tinggi.

Penyederhanaan birokrasi merupakan loncatan dari reformasi birokrasi di bidang kelembagaan/organisasi, karena didalam praktik penguatan kelembagaan pada periode I RB dan periode II RB belum mengenal adanya penyederhanaan birokrasi hanya sebatas penyederhanaan organisasi. Istilah penyederhaan organisasi digunakan pada saat mengeluarkan hasil audit/evaluasi organisasi terhadap Kementerian/Lembaga. Hasil rekomendasi tersebut berupa pemangkasan jabatan eselon I atau eselon II pada Kementerian/ Lembaga.

Penyederhanaan organisasi dapat ditemui di beberapa berita yang dipublikasikan oleh Kementerian PANRB atau media online sejak tahun 2013 dan 2014. Pada tahun tersebut memang sedang digenjot audit/evaluasi organisasi Kementerian/Lembaga. Dalam rekomendasi hasil audit organisasi itu menghasilkan dua output yaitu penyederhanaan birokrasi dan penataan ulang kelembagaan. Penyederhanaan birokrasi dilakukan untuk kementerian/ lembaga dengan merampingkan struktur birokrasi (mengurangi jabatan eselon I dan II), sedangkan untuk penataan ulang kelembagaan umunya dilakukan untuk organisasi yang non kelembagaan dengan jalan menghapus organisasi tersebut. Hasilnya pada tahun 2014 - 2017 terdapat 23 Lembaga Non Struktural yang dihapus (Road Map RB 2020-2024).

Dalam Road Map RB 2020 - 2025 penyederhanaan struktur dan kelembagaan birokrasi atau lebih dikenal dengan istilah penyederhanaan birokrasi. Dalam mewujudkan langkah penyederhanaan birokrasi Kementerian PANRB mengeluarkan Permenpanrb No. 28 Tahun 2019 tentang Penyetaraan Jabatan Administrasi Ke Dalam Jabatan Fungsional. Kemudian disusul dengan Surat Edaran Kementerian PANRB Nomor 384, 390 dan 391 Tahun 2019 perihal langkah strategis dan konkrit penyederhanaan birokrasi pada Kementerian/Lembaga dan Pemerintah Daerah. Ada sembilan (9) langkah strategis penyederhanaan birokrasi, dimulai dengan mengidentifikasi unit kerja eselon III, IV, dan $\mathrm{V}$ yang dapat disederhanakan dan dialihkan jabatan strukturalnya sesuai peta jabatan di masing-masing instansi. Kemudian dilakukan pemetaan jabatan pada unit kerja yang terdampak peralihan. Selanjutnya melakukan identifikasi 
kesetaraan jabatan-jabatan struktural tersebut dengan jabatan fungsional yang akan diduduki.

Penyederhanaan birokrasi merupakan bagian yang tidak bisa dipisahkan dari proses penyederhanaan organisasi yang dilaksanakan pada periode I RB dan periode II RB. Dinamika yang berjalan didalam penataan/penguatan kelembagaan merupakan praktik yang terbangun secara natural didalam Reformasi Birokrasi. Jika memotret tujuan program organisasi/ kelembagaan dari periode I RB untuk meningkatkan efesiensi dan efektifitas oranisasi, periode II RB untuk mewujudkan kelembagaan pemerintahan yang tepat ukuran, tepat fungsi, tidak tumpang tindih dan bersinergi antar instansi, maka pada periode III RB terdapat perubahan besar penataan/ penguatan kelembagaan melalui kebijakan penyederhanaan birokrasi.

Perubahan besar dalam penyederhanaan birokrasi mendapat respon yang sangat beragam dari kementerian/lembaga dan pemerintah daerah. Dapat dilihat dari jadwal penyederhanaan birokrasi yang harusnya pemetaan jabatan struktrual eselon III dan IV itu sudah rampung pada bulan desember tahun 2019 berdasarkan Surat Edaran Kementerian PANRB Nomor 384, 390 dan 391 Tahun 2019 dan telah rampung pada bulan juni 2020 tetapi sampai pada tanggal 24 Agustus 2020 masih ada Kementerian/Lembaga yang masih dalam proses pembahasan (Situmorang, 2020). Penyederhanaan struktur dan kelembagaan birokrasi menjadi langkah serius pemerintah untuk menyetarakan jabatan struktural eselon III dan IV kejabatan fungsional. Dalam penjelasan model birokrasi yang dikemukakan Situmorang $\mathrm{CH}$ (2020) model alternatif birokrasi yang dapat diterapkan didalam UU No. 5 Tahun 2014 ada dua yaitu Holakrasi dan agile organization. Kedua model tersebut juga sudah dikaji oleh lembaga penelitian tetapi penyederhanaan birokrasi terus berjalan untuk menemukan sendiri model yang cocok dengan karakter organisasi pemerintah di Indonesia.

\section{Kesimpulan}

1. Penataan/penguatan kelembagaan sebagai bagian dari delapan area perubahan reformasi birokrasi pada periode I dan II RB bertujuan untuk melakukan efesiensi dan efektifitas oranisasi serta tepat organisasi yang tepat ukuran, tepat fungsi, tidak tumpang tindih dan bersinergi antar instansi, dari tujuan RB tersebut tidak dapat dipungkiri bahwa pada Periode III RB muncul Penyederhanaan birokrasi.

2. Penyederhanaan birokrasi dalam Reformasi Birokrasi tidak dapat dipisahkan karena merupakan alternatif solusi yang muncul dari usaha penataan kelembagaan/ organisai.

3. Penyederhaan birokrasi menjadi langkah yang besar didalam melakukan perubahan organisasi dan birokrasi yang belum ditemukan didalam Periode I dan II Reformasi Birokrasi, sehingga membutuhkan usaha bersama untuk mewujudkan penyederhanaan birorkrasi.

\section{Daftar Pustaka}

Dwiyanto, A. (2006). Reformasi birokrasi publik di Indonesia. Gadjah Mada University Press.

Dungga, W. A., \& UNG, D. F. I. S. (2010). Penataan Kelembagaan Perangkat Daerah Berdasarkan PP 41/2007. Gorontalo: Universitas Negeri Gorontalo.

Gie, K. K. (2003). Reformasi birokrasi dalam mengefektifkan kinerja pegawai pemerintahan. Workshop Gerakan Pemerantasan Korupsi: Jakarta.

Ginting, R., \& Haryati, T. (2011). Reformasi Birokrasi Publik di Indonesia. CIVIS, 1(2/Juli).

Komarudin. (2012). Penataan Struktur Birokrasi: Kementerian danLembaga Pemerintah Non Kementerian. Jurnal Pendayagunaan Aparatur Negara, II(II), 10-33. 
Siagian, S. P. (2007). Teori pengembangan organisasi. Jakarta: Bumi Aksara.

Simarmata, J. (2018). Politik hukum restrukturisasi pembentukan perangkat daerah pasca reformasi (sekilas tanggapan terhadap Peraturan Pemerintah Nomor 18 Tahun 2016 tentang Perangkat Daerah. Jurnal Legislasi Indonesia, 13(4), 347358.

Sinambela (2008), Reformasi Pelayanan Publik, Teori Kebijakan, dan Implementasi, Bumi Aksara, Jakarta

Situmorang, C. H. (2020). Study Analysis UU ASN, Menuju Penyederhanaan Birokrasi (The Act of ASN, Toward Bureaucratic Trimming). Jurnal Sosial Dan Humaniora, 4(8).

Sugiarto, Gatot (2011). Reformasi Birokrasi Menuju Pemerintahan Kelas Dunia Tahun 2025. Jurnal Pendayagunaan Aparatur Negara, edisi I (Juni).

Thoha, M. (2002). Reformasi birokrasi pemerintah. Seminar Good Goverance Di Bappenas.

\footnotetext{
Aturan

Peraturan Pemerintah No. 11 Tahun 2017 tentang Manajemen Aparatur Sipil Negara

Peraturan Pemerintah No. 41 Tahun 2007 tentang Organisasi Perangkat Daerah

Peraturan Pemerintahh No. 18 Tahun 2016 tentang Perangkat Daerah

Peraturan Presiden Republik Indonesia No. 81 Tahun 2010 Grand Design Reformasi Birokrasi 2010-2025

Peraturan Menteri Pendayagunaan Aparatur Negara dan Reformasi Birokrasi No. 20 Tahun 2010 tentang Road Map Reformasi Birokrasi 2010-2014

Peraturan Menteri Pendayagunaan Aparatur Negara dan Reformasi Birokrasi No. 11 Tahun 2015 tentang Road Map Reformasi Birokrasi 2015-2019
}

Peraturan Menteri Pendayagunaan Aparatur Negara dan Reformasi Birokrasi No. 25 Tahun 2020 tentang Road Map Reformasi Birokrasi 2020-2024

Peraturan Menteri Dalam Negeri No. 5 Tahun 2017 tentang pedoman nomengklatur perangkat daerah Provinsi dan Daerah Kabupaten/Kota yang melaksanakan fungsi penunjang penyelenggaraan urusan pemerintahan

Peraturan Menteri Dalam Negeri No. 99 Tahun 2018 Tentang Pembinaan dan Pengendalian Penataan Perangkat Daerah

Peraturan Menteri Pendayagunaan Aparatur Negara dan Reformasi Birokrasi No. 28 Tahun 2019 tentang Penyetaraan Jabatan Administrasi Ke Dalam Jabatan Fungsiona

Renstra Deputi Bidang Kelembagaan dan Tatalaksana Kementerian PAN RB 20152020 dan 2020 - 2024

\section{$\underline{\text { Berita }}$}

Berita https://tirto.id/20-tahun-reformasiyang-terjadi-sepanjang-januari-1998-cJBd - akses tanggal 17 November 2020.

Berita Langkah strategis penyederhanaan birokrasi 19 november 2019, diakses pada tanggal 22 Desember 2020 link Kementerian Pendayagunaan Aparatur Negara dan Reformasi Birokrasi Langkah Strategis Penyederhanaan Birokrasi (menpan.go.id) 